\title{
BORN GLOBAL COMPANIES. IS THIS A FUTURE FOR ECONOMY OF LATVIA? A PRELIMINARY STUDY
}

\author{
Irena VAIVODE
}

\author{
Faculty of Engineering Economics and Management, Riga Technical University, Riga, Latvia \\ E-mail: vaivodeirena@gmail.com
}

Received 06 June 2018; accepted 12 October 2018

\begin{abstract}
A small number of export-capable sectors is a factor that renders the Latvian economy sensitive to any changes in the external environment, at the same time it is an incentive to look for growth patterns. Internationalisation is a factor that brings growth. International operations can have various advantages for enterprises, particularly for high-growing companies. The born global companies will experience stronger performance in markets that are more attractive and more internationalised. For this research purposes term 'born global' author understands as a 'truly global' company as well as domestically based company with overseas operations. The novelty of the research manifests as seeking of novel information and novel solutions based on the experience of different countries. Born global companies are the research object of an investigation. The aim of the article is an analysis of external environment perspective that is necessary to predict long-term survival for every company in conjunction with economic dimensions of globalization. The research methodology is based on the overview of literature sources that attempts to describe the key drivers for early internationalization, statistics of high-growth enterprises and survival rates of newly born enterprises, success factors of high-growth enterprises. As the result framework for the future research is created.
\end{abstract}

Keywords: born-global company, business environment, entrepreneur, globalization, internationalization, national economy.

JEL Classification: F23, F62, H50, M21.

\section{Introduction}

The Latvian economy is characterized by a small number of export-capable sectors. This renders the Latvian economy particularly sensitive to any changes in the external environment, does not provide the necessary stability and sustainability, and prevents the maximum potential of the national economy from being reached. Experts acknowledge that the improvement of people's well-being can be ensured by raising capital investment in export-capable manufacturing and service sectors (NDP, 2014-2020). How does this situation correspond to the era of modern globalization, it needs to be investigated. The definition of globalization created by Council of Europe is following: “... the ever closer economic integration of all the countries of the world resulting from the liberalization and consequent increase in both the volume and the variety of international trade in goods and services, the falling cost of transport, the growing intensity of the international penetration of capital, the immense growth in the global labour force, and the accelerated worldwide diffusion of technology, particularly communications" (Eurostat 2017). Economic dimensions of globalization:

- globalized production;

- globalized markets;

- globalized markets;

- globalized business;

- globalized technology (Eurostat 2017).

The national competitive advantage is one of the features of globalization. All national business companies are involved in the globalized business environment (Vonortas and Aridi 2012). The research question: Is the born global companies a future for economy of Latvia? The research methodology is based on the overview of different literature sources that attempts to describe the following characteristics:

Copyright ( $\odot 2018$ The Authors. Published by VGTU Press.

This is an Open Access article distributed under the terms of the Creative Commons Attribution License (http://creativecommons.org/licenses/by/4.0/), which permits unrestricted use, distribution, and reproduction in any medium, provided the original author and source are credited.. 
- the key drivers for early internationalization and the need to establish born global companies;

- statistics of the distribution of high-growth enterprises and survival rates of newly born enterprises in EU countries;

- success factors of high-growth enterprises.

An analysis of external environment perspective of country is necessary to predict long-term survival of the business companies in conjunction with economic dimensions of globalization. The case studies of external business environment perspective in Estonia, Netherlands, Sweden counties with high survival rates of new enterprises are used to answer why the survival rates of companies are different in different countries.

\section{About born global companies}

There is no firm science separating global from multinationals. As a logical conclusion might be that truly "global" companies usually have a physical presence in many countries, offer a full range of services across their operating regions, and have a majority of employees and revenue outside the country of the company headquarters (Bew 2015). For this research purposes term 'born global' author understands as a 'truly global' company as well as domestically based company with overseas operations. It is important to look at the internationalization of the company as a whole. The world has witnessed dramatic changes in the past 50 years, many of which have been reflected in the international business operations (Hitt et al. 2016). A small domestic market propels countries to look for the particular ways of successful export opportunities. National competitive advantages corresponding to advantages of location and features of national economy can promote the process of looking for successful export opportunities. As pointed out (McDougall and Oviatt 2000), entrepreneurship is a question of creating higher values. The definition of international entrepreneurship, which incorporates (Covin and Slevin's 1989) three dimensions of entrepreneurial orientation is: "International entrepreneurship is a combination of innovative, proactive and risk-seeking behaviour that crosses national borders and aims to create value in organizations" (McDougall and Oviatt 2000, Knight and Cavusgil 2004, Knight and Liesch 2016).

There are five main categories that help to recognize, evaluate and exploit international entrepreneurial opportunity:

- technology;

- home country conditions;

- the entrepreneur;

- network relationships;

- attributes of company (Madsen and Servais 1997, Autio et al. 2000).
The key drivers for early internationalization and the scope of international expansion are:

- the niche strategy built up by the entrepreneur; technology;

- the network relationships built up by the entrepreneur.

The networks are a source of information to firms about foreign markets. The networks help entrepreneurs create strategic alliances or cooperation agreements with other partners of foreign markets (Oviatt and McDougall 2005, Soetanto 2018). To build the niche strategy and the network relationships the entrepreneur needs an international business opportunity based on his/her:

- experiential knowledge and international commitment (accumulated by the entrepreneur through his/ her exposure to foreign cultures, for example, prior work or study experiences) is playing an important role in early internationalization;

- educational background (proficiency in foreign languages is more important than education or age in the decision to internationalize);

- entrepreneurial orientation (has been tested by looking at his/her international commitment) (Madsen and Servais 1997, Soetanto 2018).

Entrepreneur is in the top heading of the factors influencing the process of born global internationalization, e.g. Figure 1. Success factors of born global internationalization are identified as follows: entrepreneur's international vision and experience, international knowledge, working experience, education, ability and cognition interacting with international network, local network, financial condition of company, innovation culture, unique resource, product or service, competitive market strategy, industry conditions, government policies (Andersson et al. 2015, Martina et al. 2017, Øyna et al. 2018).

Networks. As regards the other three factors reflected in the Figure 1, it should be noted that international market entry is a gradual process, starting from interactions between parties, and developing and maintaining relationships further, due to this firms work with networks of connected relationships (Sharma and Johanson 1987, Johanson and

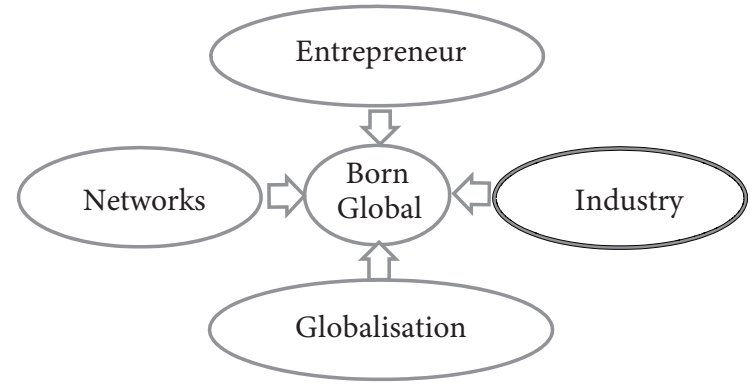

Figure 1. Factors influencing the process of born global internationalization 
Vahlne 1992). Born global companies may share resources with partners in their network, and to manage their external resource scarcity, for example, limitation of capital, equipment, country-specific knowledge, or other tangible and intangible resources. In particular, new companies are dependent on networks (Oviatt and McDougall 1994, Andersson and Wictor 2003, Chen and Shapiro 2012, Shua et al. 2017, Soetanto 2018).

Industry. The application of industry-related factors to born global companies internationalisation is rare. The term industry categorises individual companies based on common characteristics related to types of products and production technology. The influence of industry factors on the internationalisation of born global companies manifests itself as external factors influencing a company's internationalisation process including the international integration of the industry, international competitiveness, and a small domestic market (Fernhaber et al. 2007, Cavusgil and Knight 2015, Taylor and Jack 2016).

Globalization. The concept of globalization is considered as an essential factor in born global companies' internationalization process. Developments due to globalization has increased the exchange of resources and contributed to economic growth around the world (Cavusgil et al. 2014). The globalization has made it easier for companies to develop their business and to enter the international market. The increased access to global resources is a source to integrate markets, enhance relationship building and create more efficient knowledge sharing (Andersson and Wictor 2003, Huhta and Huhta 2014).

Figure 1 is based on the information obtained from conceptual framework of Andersson and Wictor (2003). By summing up factors influencing the process of born global internationalization in the interconnected world, the author has come to conclusion about their interactions within the ecosystem, e.g. Figure 2. As mentined above a successful internationalization process requires the necessary features of the entrepreneur combined with international network conditions, financial condition of company, innovation culture, unique resource, product or service, competitive

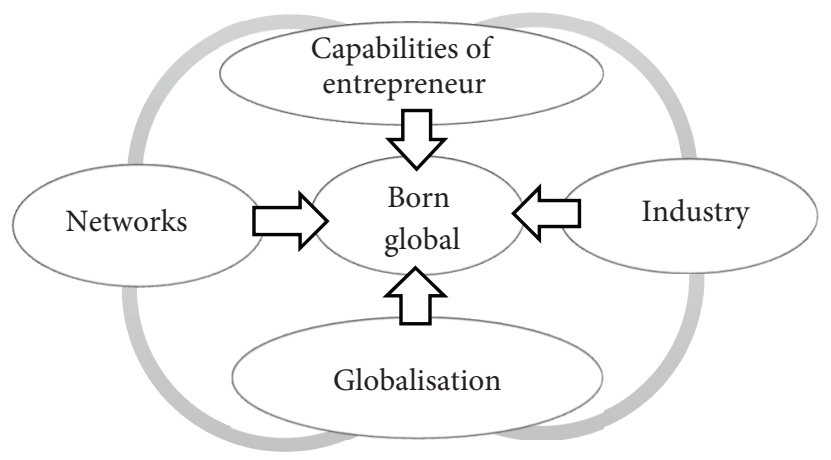

Figure 2. Factors influencing the process of born global internationalization market strategy, industry conditions, government policies, globalization factors.

Based on the above, we can conclude that factors influencing the process of born global internationalization (entrepreneur, networks, industry and globalisation) during the internationalization process forming a system involving a complex network of choices, all of these factors are in close interaction.

Further studies of success factors for born global internationalization have gone deeper and provide the following grouping of factors (see Table 1) (Andersson et al. 2015).

Table 1. Factors influencing the process of born global internationalization (source: Andersson et al. 2015)

\begin{tabular}{|l|l|l|}
\hline \multicolumn{1}{|c|}{ Entrepreneur } & $\begin{array}{c}\text { Organizational } \\
\text { perspective, strate- } \\
\text { gic perspective }\end{array}$ & \multicolumn{1}{|c|}{$\begin{array}{c}\text { External } \\
\text { environment }\end{array}$} \\
\hline $\begin{array}{l}\text { entrepreneurial } \\
\text { perspective }\end{array}$ & financial condition & industry \\
\hline international vision & innovation culture & location \\
\hline $\begin{array}{l}\text { international } \\
\text { experience }\end{array}$ & resource & $\begin{array}{l}\text { government } \\
\text { policies }\end{array}$ \\
\hline $\begin{array}{l}\text { international } \\
\text { knowledge }\end{array}$ & $\begin{array}{l}\text { unique product or } \\
\text { service }\end{array}$ & $\begin{array}{l}\text { international } \\
\text { network }\end{array}$ \\
\hline $\begin{array}{l}\text { education } \\
\text { background }\end{array}$ & $\begin{array}{l}\text { competitive } \\
\text { strategy }\end{array}$ & $\begin{array}{l}\text { market entry } \\
\text { strategy }\end{array}$ \\
\hline $\begin{array}{l}\text { entrepreneurial } \\
\text { cognition }\end{array}$ & & \\
\hline ability & & \\
\hline personal network & & \\
\hline
\end{tabular}

Mentioned above four factor groups as Entrepreneur; Organizational Perspective; Strategic Perspective; External Environment (see Table 1) could be the basis for the more advanced figure of factors influencing the process of born global internationalization compared to previous ones (e.g. Figure 1, Figure 2).

The recent research of Paul Coyle includes all of the above mentioned. Entrepreneur in his opinion is an integral part of the business ecosystem (see Table 2). Professor Paul Coyle, the Director of Executive Education at UIIN and an expert on the entrepreneurial mind set concept, developed the 'six characteristics' model that defines the entrepreneurial mind set of individuals. The model is built on his experience as a university leader. He enables others to become more entrepreneurial in their daily work and change the environment around them in the following way:

- seeing and creating opportunities;

- reading the way;

- managing risk;

- turning ideas into action;

- using resources smartly;

- collaboration for shared value. 
Author emphasizes importance of the managing risk in the following way (potential losses and threats):

- embarrassment;

- loss of reputation and credibility;

- difficult relationships with other;

- exclusion from opportunities in future;

- demotion, loss of status;

- no tenure, dismissal.

Reasons for not taking risk:

- never taken a risk before;

- easier to stay where you are;

- afraid of the consequences if something goes wrong;

- no consequences if you don't take risks;

- taking risk is not rewarded;

- prior bad experience (Coyle 2017).

Although the role of the entrepreneur has been studied thoroughly, it is important to take into account that all the business organizations are affected by the environment. Born global companies "require skills at geographic and activity coordination to develop" and they are "socially complex inimitability with close network alliances in multiple countries" (Oviatt and McDougall 1994). Born global companies need to pay attention because they "... are often drivers of national economic development and innovativeness" (Rialp et al. 2015, Choquette et al. 2017), “... 'born global' firms represent important contributors to many economies. .. (Zander et al. 2015, Choquette et al. 2017). It is important to perceive mentioned above fact that 'born global' are often drivers of national economic development and innovativeness as one of the basic assumptions for growth patterns of national economy.

Table 2. Characteristics of entrepreneurial leader provided from Coyle (source: Coyle 2017)

\begin{tabular}{|l|l|l|}
\hline Behaviours & \multicolumn{1}{|c|}{ Experience } & Entrepreneurial Experience \\
\hline Trusts & $\begin{array}{l}\text { Strength in their } \\
\text { academic field }\end{array}$ & $\begin{array}{l}\text { Commercial thinking and } \\
\text { awareness. Delivered change } \\
\text { and demonstrated impact } \\
\text { in their field due to creative, } \\
\text { proactive and risk aware } \\
\text { approach }\end{array}$ \\
\hline $\begin{array}{l}\text { Decisive, } \\
\text { Strategic }\end{array}$ & $\begin{array}{l}\text { Expert know how } \\
\text { and aware of re- } \\
\text { cent developments }\end{array}$ & $\begin{array}{l}\text { Commercial thinking and } \\
\text { awareness, has understand } \\
\text { and managed risks, has } \\
\text { identified opportunities } \\
\text { with internal and external } \\
\text { shareholders }\end{array}$ \\
\hline $\begin{array}{l}\text { Fair, } \\
\text { Supportive }\end{array}$ & $\begin{array}{l}\text { Has taken indivi- } \\
\text { dual and collective } \\
\text { responsibility }\end{array}$ & $\begin{array}{l}\text { Connected to the environ- } \\
\text { ment/ customer and clear } \\
\text { about market need. Has } \\
\text { built and maintained pro- } \\
\text { ductive external networks }\end{array}$ \\
\hline $\begin{array}{l}\text { Team play- } \\
\text { er/ team } \\
\text { builder }\end{array}$ & $\begin{array}{l}\text { Engaged with their } \\
\text { own professional } \\
\text { development }\end{array}$ & $\begin{array}{l}\text { Engaged students in social } \\
\text { entrepreneurship, interns- } \\
\text { hips etc. }\end{array}$ \\
\hline
\end{tabular}

\section{Statistical analysis of survival rates of high growth companies}

Factors influencing the process of born global internationalization and characteristics of entrepreneurial leader is a body of knowledge existing in the phase of the establishment and early growth of born global (Oviatt and McDougall 1995, Oviatt and McDougall 1997, Øyna et al. 2018). A stable leadership drives survival processes because of the experience and reputation that the founders and CEOs have built with their clients. The knowledgecreation and renewal capabilities are generally stronger in those companies that had a stable leadership (Khan et al. 2018, Naqshbandi and Jasimuddin 2018). Is the stable management the only factor that drives survival processes of the company? An in-depth study is needed about the survival rates of business companies in different countries. Considering the mentioned above, an analysis could start with statistics reflected in the study of KfW Research according high-growth enterprises. It is worth analysing as a potential early orientation to international born global (Fernhaber et al. 2007, Fernhaber et al. 2008, Bibua et al. 2016, Zimmermann 2017). For the beginning the Table 3 provides statistics of high-growth enterprise shares by economic sectors, comparison of the EU as a whole and Latvia.

Table 3 reflects considerable variations observed across EU Member States as a whole and in Latvia separately the distribution of high-growth enterprises. An integral part of this case is total survival rates of enterprises (see Table 4). Figure 3 reflects newly born enterprise death rates after 1 st and 2 nd year at the EU average, and at nine of Member States. Eurostat data of 2015 are available.

Table 3. Statistics of high-growth enterprise shares by economic sectors, comparison of the EU as a whole and Latvia (source: Eurostat 2017)

\begin{tabular}{|l|c|l|c|}
\hline $\begin{array}{c}\text { High-growth enterprise } \\
\text { shares by economic } \\
\text { sectors in the EU }\end{array}$ & $\%$ & $\begin{array}{c}\text { High-growth } \\
\text { enterprise shares by } \\
\text { economic sectors } \\
\text { in Latvia }\end{array}$ & $\%$ \\
\hline $\begin{array}{l}\text { Information and commu- } \\
\text { nication }\end{array}$ & 15 & Construction & 16 \\
\hline $\begin{array}{l}\text { Administrative and } \\
\text { support service activities }\end{array}$ & 13 & $\begin{array}{l}\text { Wholesale and retail } \\
\text { trade }\end{array}$ & 16 \\
\hline $\begin{array}{l}\text { Transport and storage } \\
\text { Scientific and technic } \\
\text { activities }\end{array}$ & 12 & $\begin{array}{l}\text { Transport and } \\
\text { storage }\end{array}$ & 15 \\
\hline $\begin{array}{l}\text { Water supply, sewerage, } \\
\text { waste management }\end{array}$ & 9 & $\begin{array}{l}\text { Administrative and } \\
\text { support service } \\
\text { activities }\end{array}$ & 6 \\
\hline Manufacturing & 8 & Real estate & 5 \\
\hline
\end{tabular}


According to Table 4, the five-year survival rates of enterprises born in 2010 and still active in 2015 shows that typically less than half of them survive for a five - year period. Enterprises in Sweden, Estonia and the Netherlands, born in 2010 (figures are underlined in Table 4) are most likely to

Newly born enterprises don't have survived after 1 st and 2 nd year (\%)

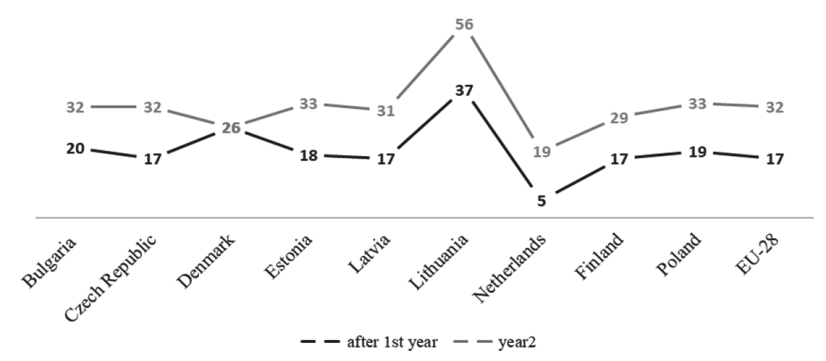

Figure 3. Newly born enterprises have survived after 1st and 2nd year

Table 4. The rates of one, three and five-year survival enterprises in 2015 (source: author's original, based data of Eurostat 2017)

\begin{tabular}{|l|c|c|c|}
\hline \multicolumn{1}{|c|}{ Country } & 1 year & 3 years & 5 years \\
\hline Bulgaria & 81 & 59 & 40 \\
\hline Czech Republic & 82 & 57 & 45 \\
\hline Denmark & 75 & 55 & 50 \\
\hline Estonia & 82 & 58 & 50 \\
\hline Latvia & 82 & 58 & 38 \\
\hline Lithuania & 65 & 40 & 32 \\
\hline Netherlands & 97 & 70 & 52 \\
\hline Finland & 82 & 55 & 38 \\
\hline Poland & 83 & 56 & 40 \\
\hline Sweden & 98 & 75 & 58 \\
\hline
\end{tabular}

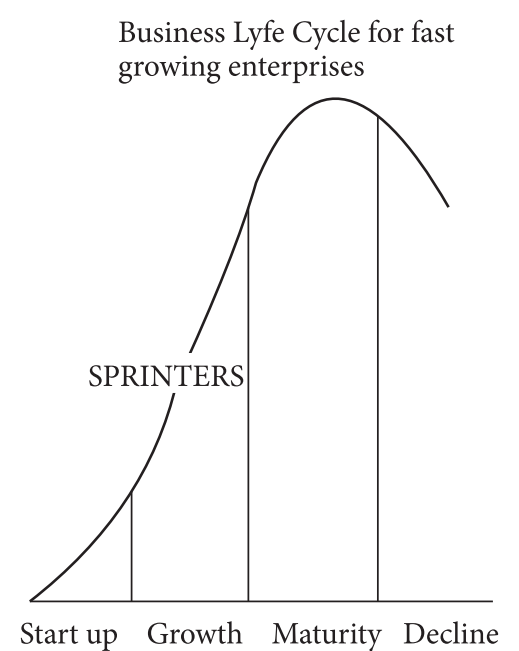

Figure 4 . Business life cycle of high growth enterprises survive up to the fifth year after their birth. It is important to find out which group of the factors: entrepreneurial factor, organizational perspective, strategic perspective or external environment affects this result. An important reason why these statistics table (see Table 4) should be created is connection with the phases of the life cycle of high growing companies (see Figure 4). In early growth (sprinters) phase fast-expanding dynamic enterprises often generate a large amount of turnover. Sprinters is the subset of high-growth enterprises which are three to five years old (Geoghegan and Mirfin 2010).

It is important get the support and to make the right decisions during this phase in order to achieve the next maturity phase. High growth enterprises is part of the national business ecosystem, therefore general information on the rates of one, three and five-year survival enterprises helps to get understanding about the situation in the national business community as a whole including high growth enterprises as part of the national business ecosystem. A new company typically proceeds through three stages: startup, growth, maturity. The challenge in startup is to define and approve the business concept and the business model. Growth is a period of company building it is the most critical period in the life of an emerging firm as it grows up and evolves. Period requires structure, process, discipline, and consistent profitability to provide a return for investors and fund the drive to market leadership. The entrepreneur must simultaneously confront multiple operational and management challenges. The skills required to lead a rapidly growing firm in a competitive environment are very different from those initially required to launch an enterprise (Persinger et al. 2007, Picken 2017). Research of the entrepreneurial perspective could help to define key factors that are decisive for the most critical period in the life of an emerging firm - period of growth.

\section{Success factors of high-growth enterprises}

Age and size have a strong influence on the growth of an enterprise, therefore the statistics of survival rates of enterprises are provided before the analysis of success factors. Author would like to illustrate this with the following example: KfW Research company (Germany) in 2017 had provide an analysis conducted with the aid of a logit model. It was based on nearly 15,600 observations of 7,300 different, mostly small enterprises. Thus, the median in the sample is merely 13 employees. The growth observation period covers the years 2011 to 2015 . A total of $2.7 \%$ of the observations included in the analysis meet the criterion for fast-growing enterprises. The likelihood of being a fastgrowing enterprise decreases from $3.4 \%$ for a five-year-old enterprise by significantly more than half to $1.5 \%$ for a 50-year-old enterprise (Zimmermann 2017). 
Fast growing enterprises are very important in economic policy debate because they stand for growth and employment creation. There is no generally accepted definition of growth enterprises. Usually (at least in this case) an enterprise as fast-growing classified when the number of employees (measured in full-time equivalents) grows by at least $50 \%$ within a two-year period.

As a result of the study are identified the factors of success:

- early orientation to international markets;

- an innovation strategy based on research and development (R\&D);

- the workforce, or human capital, is among an enterprise's most important resources, it is deemed a key success factor for achieving competitive advantages.

Internationalisation brings growth international operations can have various advantages for enterprises. Tapping into foreign markets increases demand for their products and services and the resulting larger market enables them to realise economies of scale. They can also source from other countries production factors that are scarce or relatively expensive, such as labour and capital, but also commodities and advance deliveries. International operations facilitate the integration into their own business of technologies newly developed abroad and knowledge not yet widespread on the domestic market (spill overs) (Burgel et al. 1998, Zucchella et al. 2007).

$\mathrm{R} \& \mathrm{D}$-based innovation strategy is a driver of growth. The present analysis revealed that enterprises with $\mathrm{R} \& \mathrm{D}$ activities are $45 \%$ more likely to belong to the group of highgrowth enterprises than those without R\&D activities of their own.

Age and size also have a strong influence on the growth of an enterprise. The likelihood of being a fast-growing enterprise decreases from 3.4\% for a five-year-old enterprise by significantly more than half to $1.5 \%$ for a 50 -year-old enterprise. With respect to enterprise size, that likelihood decreases from $3.6 \%$ for an enterprise with two employees to $1.4 \%$ for an enterprise with 34 employees. Entrepreneurs below the age of 40 are most likely to be managing a growth enterprise, at $4.2 \%$. Up to an age of more than 60 years, that probability drops to $1.1 \%$ (Zhu 2010, Frederiksa et al. 2018, Khana et al. 2018).

Past studies have also shown that business growth is associated with higher investment activity. Nevertheless, various features can be identified that distinguish fast-growing enterprises from their more slowly developing counterparts. These include the age and initial size of the enterprise and, in particular, employment, international orientation and pursuit of an R\&D-based innovation strategy. Besides internal factors, it is also highly dependent on the environment in which it operates (Bangs 2002, Zimmermann 2017).

\section{The role of external environment perspective}

A highly internationalised market may provide firms with the benefits associated with a wider international network. The born global will experience stronger performance in markets that are more attractive and more internationalised (Gerschewski et al. 2015, Nemkova 2017). As internationalisation brings growth, international operations can have various advantages for enterprises, particularly for highgrowing companies. Behaviour, experience of entrepreneur should be in line with the processes of globalization. Human capital is a success factor the workforce is among an enterprise's most important resources. Those are not enough indicators to analyse differences in enterprise survival rate of different countries. Thereby the external environment perspective as industry conditions and government policies would be the object of investigation. The role of an external environment for improving survival rates of enterprises is illustrated by the following cases.

\subsection{External business environment perspective of the Netherlands}

The sectors that make the highest contribution to Dutch GDP:

- business services (21.3\%);

- trade, transport and communication (21.1\%);

- and manufacturing (14.2\%).

The Netherlands has developed a strong presence in technology-related industries such as biotechnology, fine chemicals, food, pharmaceuticals, electronics, medical technology and printing. A few of the areas of importance in the industry sector are:

- cooperation,

- innovation,

- internationalisation,

- sustainability.

Industry has a strong international focus. As a result, development of exports, raw materials prices and the global economy are essential factors (ABN AMRO 2009).

The Netherlands is considered to be one of the most innovative economies in Europe. Its public authorities are actively supporting research and innovation in the Dutch academies and private sector. In the programming period 2014-2020, around 66\% of the investment is focused on the promotion of the innovation-friendly business environment (European Parliament 2015).

\subsection{External business environment perspective of Sweden}

Sweden is integrated into the global economy country has strong trade and investment activity relative to the size of its economy. The trade profile of Sweden is following: 
- services have become more important sector of export;

- goods exports have shifted towards a larger role of natural-resource driven products.

Among trading partners, neighbour countries dominate. Most exporters are large companies but smaller companies have seen their role in trade increase (Ketels 2012).

Capital market infrastructure is as follows:

- protection of shareholders' interests;

- ease to access to loan;

- venture capital availability;

- regulation of securities exchange;

- financial market sophistication;

- soundness of banks;

- domestic credit to private sector.

Innovation infrastructure is as follows:

- quality of scientific research institutions;

- availability of scientists and engineers;

- university-industry research collaboration;

- utility patents per millions population;

- quality of management schools (Ketels 2012).

There is a high level of dynamism of fast growing firms gazelles. A strong investment effort and desired business environment promote the process (World Bank Group 2014).

Gazelles are less likely to be constrained by the such components of business environment than other firms:

- taxes and contributions;

- labour laws;

- market demand;

- duration of fixed-term contracts;

- redundancy laws;

- shortage of skilled workers;

- tax rates;

- complexity of tax rules;

- frequent changes in tax rules;

- political instability (World Bank Group 2014).

84 percent of the Swedish firms are in the manufacturing sector, 44 percent of the exporting firms from this sector engage in $R \& D$, compared with 35 percent of no exporting firms. In the services sector, with only 22 percent of exporting firms conducting R\&D activity, compared to 29 percent of no exporting firms (World Bank Group 2014).

Conclusion: The mentioned above is the result of a strong investment effort, Sweden's integration into the global economy, quality of scientific research institutions, availability of scientists and engineers, university-industry research collaboration.

\subsection{External business environment perspective of Estonia}

Estonia presents a range of national support schemes for business. Enterprise Estonia (EAS) is one of the largest institutions within the national support system for entrepreneurship, providing financial assistance, advisory, cooperation opportunities and training for entrepreneurs, research establishments, public and the third sector. Pursuant to the accession of Estonia to the European Union, EAS became one of the implementing units of the European Union structural funds in Estonia (Ernst and Young 2012). Today, most of the EAS programs and grants offered are financed from the EU structural funds. EAS has foreign representative offices in Hamburg, Helsinki, Kyiv, London, Moscow, Shanghai, Silicon Valley, Stockholm, St. Petersburg and Tokyo (Ernst and Young 2012).

Businesses can also get support from the Credit and Export Guarantee Fund Kred Ex in Estonia. The support schemes include, for example, a start-up loan to finance investments and working capital of starting businesses (Ernst and Young 2012).

Considerations to invest in Estonia:

- Estonia is the politically stable country;

- Estonia does not have corporate income tax on reinvested profits, country has the lowest public debt in the EU;

- Estonia has highly educated and motivated human resources;

- Estonia has wide range of state e-services, e-banking, nationwide ID-card;

- Estonia is a most transparent and the least corrupt country in Central and Eastern Europe (Transparency International 2015);

- one of the highest economic freedom in the World and the best in EU;

- regulatory environment is appropriate for starting and operating a company (Doing Business 2014).

The business climate in Estonia is characterised as free business and trade in alignment with EU practices. The economic and fiscal policy of the Government is aimed at achieving long-term economic growth. The Government attitude is welcoming toward foreign capital, especially into sectors that are export oriented, innovative and support regional development (PwC 2016).

Conclusion: The mentioned above is the result of a range of national support schemes for business, highly educated and motivated human resources, the fact that Estonia is a most transparent and the least corrupt country in Central and Eastern Europe with the economic and fiscal policy of the Government aimed at achieving long-term economic growth.

The common features of external economic environment of the Netherlands, Sweden and Estonia: national support schemes for business, strong investment effort, integration into the global economy, support for research and innovation, university-industry research collaboration. 


\section{The framework for the future research}

The somewhat different investigations and sources of literature are available if we want to get an idea of the Latvian business environment.

The main ideas reflected in Baltic CEOSurvey (2016): unsettled business environment is the top concern of Latvian CEOs; $93 \%$ of Latvian CEOs say that competition in their industry will grow over the next three years and attract new customers, they will recruit top talent, create innovative solutions, implement and integrate new technology with existing systems. To be better prepared for future challenges and to stay competitive, they focus on customer retention and existing markets. Most Latvian CEOs prefer to cooperate with business associations, customers and suppliers, with only $40 \%$ considering partnership with competitors, startup enterprises and government. The top three priorities of Latvian CEOs are building an internationally competitive tax system (87\%), fighting the shadow economy (66\%), and having a skilled and adaptable workforce (52\%) (Baltic CEO Survey 2016).

European Bank for Reconstruction and Development (2016) argues that Latvia's business environment is relatively positive, although there is room for improvement. A number of additional obstacles mentioned including inefficient government bureaucracy, tax regulations and access to finance. The top three business environment obstacles identified by Latvian enterprises were workforce skills, access to finance and political instability (European Bank for Reconstruction and Development 2016).

Baltic Business Outlook (2018) presents an assessment of business environment: $83 \%$ of Latvian enterprises focus their efforts on the domestic market, $75 \%$ of SMEs will try to reach their business target with the existing employees, however, $16 \%$ of respondents have reported that they will hire new people this year. Most of the industries demonstrate positive trends, for example, real estate and construction industries are planning to be particularly active during next few years - because of EU fund investments and rapid implementation of private projects. Negative trends in finance and insurance industry caused by outflow of nonresident funds will endure for the near future, perspectives for railway and ports remain unclear. Tax reform will still be within the focus during 2018, which will start with uncertainties caused by many changes in legislation norms and continuation of transition periods (Baltic Business Outlook 2018).

Considering described above features of the business environment and looking for an answer to the question "Is the born global companies a future for economy of Latvia?" the information provided initially in this article is the statistics of high-growth enterprise shares by economic sectors, comparison of the EU as a whole and Latvia (see Table 2). Highgrowth enterprises are worth analysing as a potential early orientation to international born global (Zimmermann 2017). As previously mentioned in this article, a strong investment effort and desired business environment promote the process of early orientation to international born global and the process of improving of the business survival rates (see Table 3) (World Bank Group 2014, Strategy for Latvia 2016). Author has come to the necessity of a business environment study.

Taking into account the experience of countries, described in the paragraph 3 of the current article, the framework for future research could be the following:

1. Research of the entrepreneurial perspective and entrepreneurial mindset, and awareness built and maintained productive external networks.

The need for this study follows from opinion of entrepreneurship scholars who have attempted to explain the networks role in facilitating entrepreneurial actions. Networks evolve dynamically in relation to entrepreneurial stages such as opportunity exploration, initial resource gathering, incubation, early market entry, and growth (Soetanto 2018). An essential factor is to emphasize interpersonal communication skills during networking. Entrepreneurs should be able to perceive accurately, to make good first impressions, or to change their attitudes when interacting with venture capitalists, potential customers and facing a fundamental change from traditional markets to networks of interrelated firms under the increasing competitiveness of business environments (Zahra and George 2002, Shu et al. 2017). As newly born enterprises are often accompanied by high levels of uncertainty, prior business and technology knowledge strengthens entrepreneurs position in globalised markets (Frederiks et al. 2018). The skills, knowledge, mindset required to lead a rapidly growing firm in a competitive environment are very different from those initially required to launch an enterprise.

2. Research of the business environment including Government Policies: building of the friendly business environment for investors; the necessity of active supporting research and innovation in the academies and private sector; the promotion of the innovation-friendly business environment:

- Taxes and contributions;

- Labour laws;

- Market demand;

- Duration of fixed-term contracts;

- Redundancy laws;

- Shortage of skilled workers;

- Tax rates;

- Complexity of tax rules;

- Frequent changes in tax rules.

The influence of external business environment to success factors of high-growth enterprises:

- to early orientation to international markets; 
- to an innovation strategy based on research and development $(\mathrm{R} \& \mathrm{D})$;

- to the human capital as one of an enterprise's most important resources.

This research is necessary because a highly internationalised market may provide companies with the benefits associated with a wider international network. The born global will experience stronger performance in markets that are more attractive and more internationalised (Gerschewski et al. 2015). As internationalisation brings growth, international operations can have various advantages for enterprises, particularly for high-growing companies. The linkages between entrepreneurial activity that generate value for society and national or regional economic development shifted focus from studies of entrepreneurs and firms to the creation of entrepreneurial ecosystems that include institutions, social networks, and cultural values that produce and sustain entrepreneurial activity. The interdisciplinary approach can help understand the complexity of the phenomenon. Requires an approach that pays attention to the configuration of individual, organizational, and societal forces that is necessary to promote and support entrepreneurial activities (Roundya et al. 2018).

\section{Conclusions}

Born global companies are the research object of the current study. For this research purposes term 'born global' author understands as a 'truly global' company as well as domestically based company with overseas operations. This topic was inspired by the fact that the born global companies will experience stronger performance in markets that are more attractive and more internationalised thereby it could be a solution to the situation that the Latvian economy is characterized by a small number of export-capable sectors. This renders the Latvian economy particularly sensitive to any changes in the external environment, does not provide the necessary stability and sustainability. The research methodology is based on the overview of literature sources that attempts to describe the key drivers for early internationalization, statistics of high-growth enterprises and survival rates of newly born enterprises, success factors of high-growth enterprises. The aim of the article is an analysis of external environment perspective that is necessary to predict long-term survival for every company in conjunction with economic dimensions of globalisation. The novelty of the research manifests as seeking of novel information and novel solutions based on the experience of different countries. Statistics of high growth enterprises as basis for born global is necessary to show that significant differences were observed in the distribution of highgrowth enterprises by economic sectors across the EU as a whole and in Latvia. Information and communication technologies and administrative and support service activities are at the top of the EU rating, construction and wholesale and retail trade high-growth companies is the core of this economic area in Latvia.

Need to focus on survival statistics of newly born enterprises can be explained to that all national business companies are involved in the globalized business environment. High growing enterprises is part of the national business ecosystem, therefore general information on the rates of one, three and five-year survival enterprises helps to get understanding about the situation in the national business community as a whole. In the early growth (sprinters) phase fast-expanding dynamic enterprises often generate a large amount of turnover. Sprinters is the subset of high-growth enterprises that are three to five years old. It is important to get the support you need and to make the right business decisions during this phase in order to achieve the next - maturity phase. Enterprises in Sweden, Estonia and the Netherlands, born in 2010 are most likely to survive up to the fifth year after their birth. It is important to find out which group of the factors: Entrepreneur, Organizational Perspective, Strategic Perspective or External Environment affects this result. In this regard, the case studies of external business environment perspective in Estonia, Netherlands, Sweden - counties with high survival rates of new enterprises were used to answer why the survival rates of companies are different in different countries. As a result, the following information is collected:

- the Netherlands is considered to be one of the most innovative economies in Europe its public authorities are actively supporting research and innovation in the Dutch academies and private sector, around $66 \%$ of the investment is focused on the promotion of the innovation-friendly business environment;

- a strong investment effort is realized in Sweden, country's integration into the global economy, quality of scientific research institutions, availability of scientists and engineers, university-industry research collaboration;

- there is a range of national support schemes for business, highly educated and motivated human resources in Estonia, country is a most transparent and the least corrupt in Central and Eastern Europe with the economic and fiscal policy of the Government aimed at achieving long-term economic growth.

Following this information and according to several researchers, factors influencing the process of born global internationalization and characteristics of entrepreneurial leader is a body of knowledge existing in the phase of the establishment and early growth of born global.

Taking into account the experience of countries, described in the paragraphs of this article, the research topics to be studied further could be the following: 
- research of the entrepreneurial perspective and mind set, of the commercial thinking and awareness built and maintained productive external networks;

- research of the business environment including Government Policies: building of the friendly business environment for investors; the necessity of active supporting research and innovation in the academies and private sector; the promotion of the innovationfriendly business environment.

A more detailed analysis of the situation in Latvia requires further research. Currently there are not enough investigations of external environment perspective and the entrepreneurial perspective that is necessary to predict long-term survival for every company in conjunction with economic dimensions of globalisation and answer the question how to promote fast growing companies becoming born global. There is necessity of an approach that pays attention to the configuration of individual, organizational, and societal forces that is necessary to promote and support entrepreneurial activities.

\section{Author contributions}

Author of an article conceived the study and were responsible for the design, development and data collection, analysis and interpretation as well as wrote the first draft of the article, made further corrections and improvements. Author is using sources of scientific literature and case studies of business environment of different countries affecting creation in action-accelerating knowledge for understanding, analyzing and designing ways to investigate external business environment of Latvia, to identify and define research problems which might be relevant to further research. The novelty of the research manifests as seeking of novel information and novel solutions based on the experience of different countries.

Prof. Elina Gaile-Sarkane and Assoc. Prof. Deniss Sceulovs advised the author in writing this article.

\section{Disclosure statement}

Publication in connection with the participation in Scientific Conference "Business and Management'2018" which took place on 2-4 May 2018 at the Faculty of Business Management of Vilnius Gediminas Technical University.

\section{References}

ABN AMRO (2009) The Netherlands, Gateway to the European Market. Country profile.

Andersson S (2000) The Internationalization of the firm from an entrepreneurial perspective. International Studies of Management and Organization 30: 63-92. https://doi.org/10.1080/ 00208825.2000 .11656783
Andersson S (2004) Internationalization in different industrial contexts. Journal of Business Venturing 19: 851-875. https:// doi.org/10.1080/00208825.2000.11656783

Andersson S, Danilovic M, Huang H (2015) Success factors in Western and Chinese born global companies http://www. scirp.org/journal/ib

Andersson S, Wictor I (2003) Innovative internationalization in new firms: born global - the Swedish case. Journal of International Entrepreneurship 1: 249-275. https://doi. org/10.1023/A:1024110806241

Autio E, Sapienza HJ, Almeida JG (2000) Effects of age at entry, knowledge intensity, and limitability on international growth. Academy of Management Journal 43: 909-924.

Bangs DH (2002) The business planning guide https://www.amazon.com/Business-Planning-Guide-David-Bangs/

Baltic Business Outlook (2018) SEB Bank.

Baltic CEO Survey (2016) https://www.pwc.com/lv/en/news/ pwc-baltic-ceo-survey.html

Bew R (2015) Governing the global company oversight of complexity authors. Marsh \& McLennan Companies.

Bibua NA, Salaa DC, Alba M (2016) Specific and common features in fast-growing companies from the Timiș County (Romania). In: Procedia - Social and Behavioral Sciences 221: 49-56. https://doi.org/10.1016/j.sbspro.2016.05.089

Burgel O, Murray C, Fier A, Licht G, Nerlinger E (1998) The Internationalization of British and German start-up companies in high-technology Industries. Journal of International Marketing 8: 33-62. https://doi.org/10.1509/jimk.8.2.33.19624

Cavusgil ST, Knight G, Riesenberger JR (2014) International Business - The New Realities 3. Essex: Pearson Education.

Cavusgil ST, Knight G (2015) The born global firm: an entrepreneurial and capabilities perspective on early and rapid internationalization. Journal of International Business Studies 46 (1): 3-16. https://doi.org/10.1057/jibs.2014.62

Chen VZ, Li J, Shapiro DM (2012) International reverse spillover effects on parent firms: Evidences from emerging-market MNEs in developed markets. European Management Journal 30: 204-218. https://doi.org/10.1016/j.emj.2012.03.005

Choquette E, Rask M, Sala D, Schröder P (2017) Born globals - is there fire behind the smoke? International Business Review 26: 448-460. https://doi.org/10.1016/j.ibusrev.2016.10.005

Coyle P (2017) The entrepreneurial mindset workshop designed for higher education professionals https://blog.uiin. org/2017/08/professor-paul-coyle-entrepreneurial-mindsetworkshop-designed-higher-education-professionals/

Covin JG, Slevin DP (1989) Strategic Management of Small Firms in Hostile and Benign Environments. Strategic Management Journal 10: 75-87. https://doi.org/10.1002/smj.4250100107

Doing Business (2014) Understanding Regulations for Small and Medium-Size Enterprises. Comparing Business Regulations for Domestic Firms in 189 Economies. A World Bank Group Corporate Flagship.

Ernst \& Young (2012) Doing business in Estonia www.doingbusiness.org/ /media/WBG/DoingBusiness/

European parliament (2015) Economic, social and territorial situation of the Nether-lands. In-depth analysis. DirectorateGeneral for internal policies. 
Eurostat (2017) Globalisation patterns in EU trade and investment. Luxembourg: Publications Office of the European Union http://ec.europa.eu/eurostat/about/policies/copyrig

Fernhaber SA, Oviatt PP, McDougall BM (2007) Exploring the role of industry structure in new venture internationalization. Entrepreneurship Theory and Practice 31: 517-542. https:// doi.org/10.1111/j.1540-6520.2007.00186.x

Fernhaber SA, Gilbert BA, McDougall PP (2008) International entrepreneurship and geographic location: an empirical examination of new venture internationalization. Journal of International Business Studies 39: 267-290. https://doi. org/10.1057/palgrave.jibs.8400342

Frederiksa AJ, Englis BG, Ehrenhard ML, Groena AJ (2018) Entrepreneurial cognition and the quality of new venture ideas: an experimental approach to comparing future-oriented cognitive processes. Journal of Business Venturing. https:// doi.org/10.1016/j.jbusvent.2018.05.007

Geoghegan N, Mirfin G (2010) Entrepreneur mapping. Tracking Business along. The Journey from Pre-Start to StartUp to High Growth https://www.slideshare.net/CllrMirfin/ entrepreneur-mapping

Gerschewski S, Rose EL, Lindsay VJ (2015) Understanding the drivers of international performance for born global firms: an integrated perspective. Journal of World Business 50: 558-575. https://doi.org/10.1016/j.jwb.2014.09.001

Hitt MA, Li D, Xu K (2016) International strategy: from local to global and beyond. Journal of World Business 51: 58-73. https://doi.org/10.1016/j.jwb.2015.08.016

Huhta F, Huhta H (2014) The Internationalization process within born global companies. How Swedish born globals utilize resources in the internationalization process. Umeå School of Business and Economics.

Johanson J, Vahlne JE (1992) Management of foreign market entry. Scandinavian International Business Review 1 (3): 9-27. https://doi.org/10.1016/0962-9262(92)90008-T

Khana Z, Kyu Y, Lew YK (2018) Post-entry survival of developing economy international new ventures: a dynamic capability perspective. International Business Review 27: 149-160. https://doi.org/10.1016/j.ibusrev.2017.06.001

Ketels K (2012) Sweden position in the global economy. Entreprenörskapsforum.

Knight GA, Cavusgil ST (2004) Innovation, organizational capabilities, and the born global firm. Journal of International Business Studies 35: 124-141. https://doi.org/10.1057/ palgrave.jibs. 8400071

Knight GA, Liesch PW (2016) Internationalization: from incremental to born global. Journal of World Business 51: 93-102. https://doi.org/10.1016/j.jwb.2015.08.011

Madsen TK, Servais P (1997) The Internationalization of Born Globals: An Evolutionary Process? International Business Review 6: 561-583. https://doi.org/10.1016/S0969-5931(97) 00032-2

Martina SL, Javalgi RG, Cavusgil E (2017) Marketing capabilities, positional advantage, and performance of born global firms: contingent effect of ambidextrous innovation. United States International Business Review 26: 527-543. https://doi. org/10.1016/j.ibusrev.2016.11.006
McDougall PP, Oviatt BM (2000) International Entrepreneurship: The Intersection of Two Research Paths. Academy of Management Journal 43: 902-906.

Naqshbandi MM, Jasimuddin SM (2018) Knowledge-oriented leadership and open innovation: role of knowledge management capability in France-based multinationals. International Business 27 (3): 701-713. https://doi.org/10.1016/j. ibusrev.2017.12.001

National Development Plan of Latvia for 2014-2020 (2014-2020) Cross-Sectoral Coordination Centre.

Nemkova E (2017) The impact of agility on the market performance of born-global firms: an exploratory study of the 'Tech City' innovation cluster. Journal of Business Research 80: 257-265. https://doi.org/10.1016/j.jbusres.2017.04.017

Øyna S, Almor T, Elango B, Tarba SY (2018) Maturing born global and their acquisitive behavior. International Business Review 27: 714-725. https://doi.org/10.1016/j.ibusrev.2017.12.002

Oviatt B, McDougall P (1994) Toward a theory of international new ventures. Journal of International Business Studies 25 (1): 45-64. https://doi.org/10.1057/palgrave.jibs.8490193

Oviatt BM, McDougall PP (1995) Global Starts-Ups: entrepreneurs on a worldwide stage. The Academy of Management Executive 9: 30-44.

Oviatt BM, McDougall PP (1997) Challenges for internationalization process: the case of international new venture. Management International Review 37 (2): 85-99.

Oviatt BM, McDougall PP (2005) Defining International Entrepreneurship and Modeling the Speed of Internationalization. Management International Review 37: 85-99. https://doi. org/10.1111/j.1540-6520.2005.00097.x

Persinger ES, Civi E, Vostina SW (2007) The born global entrepreneurs in emerging economies. International Business and Economics Research Journal 6: 73-82.

Picken JC (2017) From founder to CEO: An entrepreneur's roadmap. Business Horizons 60: 7-14. https://doi.org/10.1016/j. bushor.2016.09.004

PwC (2016) Doing business and investing in Estonia https://www. pwc.com/ee/et/publications/DoingBusinessinEstonia

Rialp A, Rialp J, Knight G (2015) International entrepreneurship: a review and future directions. Routledge.

Roundya PT, Bradshaw M, Brockman BK (2018) The emergence of entrepreneurial ecosystems: a complex adaptive systems approach. Journal of Business Research 86: 1-10. https://doi. org/10.1016/j.jbusres.2018.01.032

Sharma D, Johanson J (1987) Technical consultancy in internationalisation. International Marketing Review 4 (4): 20-29. https://doi.org/10.1016/j.jbusres.2018.01.032

Shua R, Ren S, Zheng Y (2017) Building networks into discovery: the link between entrepreneur network capability and entrepreneurial opportunity discovery. Journal of Business Research 85: 197-208. https://doi.org/10.1016/j.jbusres.2017.12.048

Soetanto D (2018) Examining change in entrepreneurial networks: using visualization as an alternative approach. European Management Journal. https://doi.org/10.1016/j.emj.2018.05.001

Strategy for Latvia (2016) Document of the European Bank for Reconstruction and Development https://www.ebrd.com/documents/strategy-and-policy-coordination/strategy-in-latvia.pdf 
Taylor M, Jack R (2016) Born global firm internationalisation: the influence of industry factors. Contemporary Management Research Pages 12 (3): 289-308. https://doi.org/10.7903/ cmr.14892

Transparency International (2015) Corruption Perceptions Index https://www.transparency.org/cpi2015

Vonortas NS, Aridi A (2012) Innovation policy handbook. Center for International science and technology policy.

World Bank Group (2014) Sweden's business climate. A microeconomic assessment http://www.enterprisesurveys.org

Zahra SA, George G (2002) International entrepreneurship: the current status of the field and future research agenda. strategic entrepreneurship: creating a new mindset. Blackwell Publisher, Oxford, 255-288.

Zander I, McDougall P, Rose EL (2015) Born global and international business: Evolution of a field of research. Journal of International Business Studies 46: 27-35. https://doi. org/10.1057/jibs.2014.60

Zimmermann V (2017) KfW research focus on economics success factors of high-growth enterprises https://www.kfw. de/PDF/Download-Center/Konzernthemen/Research/PDFDokumente-Fokus-Volkswirtschaft/Fokus-englische-Dateien/ Fokus-2017-EN

Zhu JQ (2010) Research on the driving forces of new ventures internationalization from the entrepreneur perspective. Shanghai Management Science 32: 13-17.

Zucchella A, Palamara G, Denicolai S (2007) The drivers of the early internationalization of the firm. Journal of World Business 42: 268-280. https://doi.org/10.1016/j.jwb.2007.04.008

\section{APPENDIX}

\author{
Notations \\ Abbreviations \\ CEO - chief executive officer \\ EAS - Enterprise Estonia \\ EU - European Union \\ GDP - Gross Domestic Product \\ R\&D - Research and Development \\ NDP - National Development Plan \\ PwC - Pricewaterhouse Coopers \\ SME - Small and Medium-Sized Enterprises \\ UIIN - University Industry Innovation Network
}

